\title{
Economic Instrument in Environmental Management: A Case Study of Environmental Protection Tax in Vietnam
}

\author{
Dinh Duc Truong \\ Faculty of Environment, Climate Change and Urban Studies, National Economics University, 100000, Hanoi, Vietnam
}

Received August 11, 2021; Revised September 29, 2021; Accepted October 21, 2021

\section{Cite This Paper in the following Citation Styles}

(a): [1] Dinh Duc Truong, "Economic Instrument in Environmental Management: A Case Study of Environmental Protection Tax in Vietnam," Environment and Ecology Research, Vol. 9, No. 5, pp. 300 - 313, 2021. DOI: 10.13189/eer.2021.090509.

(b): Dinh Duc Truong (2021). Economic Instrument in Environmental Management: A Case Study of Environmental Protection Tax in Vietnam. Environment and Ecology Research, 9(5), 300 - 313. DOI: 10.13189/eer.2021.090509.

Copyright $@ 2021$ by authors, all rights reserved. Authors agree that this article remains permanently open access under the terms of the Creative Commons Attribution License 4.0 International License

\begin{abstract}
Because of its fast economic expansion in recent decades, Vietnam, a developing country, is increasingly plagued by environmental degradation. Vietnam is also one of the five countries most affected by climate change. In 2012, the government enacted the Environmental Protection Tax Law, which included a broad-based package of environmental levies. The implementation of the Environment Protection Tax (EPT) is one component of a larger process of greening the Vietnamese economy. Environmental taxes have the potential to alleviate some of the environmental issues that developing countries face. At the same time, it promotes long-term patterns of production and consumption. This offers financial resources required to enhance social and environmental indices. However, environmental taxes may have both direct and indirect consequences, such as increased prices for products and services, which have a detrimental impact on social justice, particularly in low-income households. This page will give a more in-depth explanation of environmental protection tax implementation, accomplishments, and impacts. It is also responsible for analyzing issues and making recommendations for future EPT improvements.
\end{abstract}

Keywords Economic Instrument, Environmental Management, Environmental Protection Tax, EPT, Vietnam

\section{Introduction}

Environmental problems are putting greater pressure on the government to seek ways to reduce damage to the environment while maintaining economic growth. Governments can employ various tools, from Law to information efforts and innovation policies to environmental and environmental charges. Taxes are a key element of this set, in particular.

Environmental taxes provide a wide variety of important benefits, including environmental efficiency, economic efficiency, public income capacity, and openness. Furthermore, the environmental fee has successfully handled several problems, including garbage disposal, water contamination, and pollutants. Whatever the policy area, the application of the environmental tax and the concerns of the political economy are crucial variables for determining the effectiveness of environmental taxation application [1].

Vietnam, a developing country, has been increasingly affected by environmental pollution due to rapid economic development during recent decades. Air pollution caused by burning fossil fuels for power production and transportation is increasingly negatively influencing the Vietnamese people's life expectancy [1]. Deforestation, soil degradation, air, soil, water pollution, and poor resource management are obstacles to poverty alleviation. Vietnam is also among the five nations most severely impacted by climate change [3]. 
The Vietnamese Environmental Protection Tax Act in 2012, known as Act 57/2010/QH12, has established a broad-based environment tax package. EPT adoption is one aspect in the wider process of greening the Vietnamese economy, as outlined by the greening of the Vietnamese economy (VGGS, Viet Nam Green Growth Strategy, 2012)[1]. In the last several years, the VGGS has also given more attention to implementing the sustainability targets and complying with the Paris Agreement obligations.

According to Jacqueline Cottrell and Tatiana Falcão [1], environmental taxes can solve some ecological problems facing developing countries. At the same time, it encourages sustainable patterns of production and consumption. This provides the necessary financial means to improve social and environmental indicators. However, environmental taxes may result in direct and indirect effects, such as price increases of goods and services, negatively impacting social equity, particularly in poor households [2].

This study looks at a case study of environmental taxation in Vietnam. The first objective of the report is to provide a deeper understanding of environmental protection tax implementation. Also, its achievements, environmental, economic, and social impacts are included in this objective. The second objective of the study is to analyze issues related to environmental protection tax design and implementation. The third objective of this study is to provide recommendations for EPT improvement in the context of sustainable development in Vietnam.

\section{Materials and Methods}

\subsection{Literature Review}

Environmental tax is a charge placed on activities that are deemed environmentally damaging. It encourages eco-friendly activities through economic incentives. A Pigouvian environmental tax is intended to make up for market failings in responding to the lack of environmental characteristics and stimulate more sustainable practices [4]. Taxes solve the market failure quickly, leading to markets being unaware of environmental implications. A well-planned environmental tax increases the cost of an item or activity to reflect the costs of the damage brought to others by the environment. Therefore, the cost of harming people - termed as an "externality" - is included in the market price. Consumers and businesses thus take account of these expenses in their decisions. In summary, the tax aligns economic activity's marginal private expenses with the marginal societal cost to promote ecologically friendly production [5].

Environmental taxes have been applied in many OECD countries. Simulation modeling conducted by the OECD shows that removing fuel subsidies in OECD countries, using an energy tax linked to carbon, and taxing all chemicals could significantly reduce pollution at almost negligible economic cost [6]. The United Nations Environment Program's Global Environmental Outlook 3 also supported the removal of subsidies and the introduction of green taxes [7]. Environmental taxes can solve ecological problems in developing countries. It also promotes sustainable patterns of production and consumption. Thereby, it provides the financial means necessary to enhance environmental and social indicators. However, environmental taxes can, directly or indirectly, increase the prices of goods and services. This causes a negative impact on social justice, especially for poor households $[8,9]$.

Tax can assist in boosting government revenue. The relative significance of income increase and expenditure is shown in the OECD DAC (OECD Development Assistance Committee) criteria for environmental reform in developing countries. By tackling environmental concerns which impact the poor and indirectly by producing or freeing up resources for anti-poverty work $[8$, 9], EFR can help directly to poverty reduction. The advantage of adopting a tax system is that there are generally already administrative resources. Additional advantages are also provided by the flexibility of environmental tax response: (i) Continuous reduction incentive. A technology-based or goal-based policy does not provide an opportunity to decrease the target or technological standard after it is attained. Environmental taxes, in contrast, continue to encourage a decrease in all emissions, even when a substantial decrease has already happened. (ii) Enhance the competitiveness of low alternative emissions. Environmental taxes stimulate demand for alternative low-emission products such as public transit and cycling in the case of car fuel taxes. It leads to economies of scale that make these alternatives more viable without direct support. (iii) Innovative, strong stimulus. Taxes increase polluter costs and encourage companies to innovate and adapt to current innovations. Taxes increase pollutant costs. These incentives evaporate as soon as companies comply with the regulated norm under regulatory techniques. The cost of tackling environmental issues in the long term is decreased through increased innovation for society [8].

For governments to contemplate extra taxes, acceptability from the community is an essential issue. Studies show that the acceptability levels will be low if the revenues from the tax merely go into the general income. On the other hand, if special accounts for the revenues like environmental levies imposed by municipal councils, such as accounts of the trust, are formed, the level of acceptance is significantly greater. It is an essential factor in encouraging and enhancing the political will to levy such levies.

When considering the impact of environmental taxes, 
some green tax transition proposals are financially constrained. Taxing negative externalities often imposes a burden on consumption. Since the poor typically consume more and save or invest less than their income, any change to the consumption tax could be regressive. In 2004, research by the Institute for Policy Studies and the Joseph Rowntree Foundation showed that fixed tax rates on household waste, energy, water, and transportation would have a relatively high impact on poor households. However, conventional approaches can similarly affect prices, while an environmental tax has no revenue potential [9].

Furthermore, an accurate assessment of the impact of any tax change requires an analysis of instrument design features. For example, tax revenue can be redistributed per capita as part of basic income. In this case, the poorest get what middle-income people pay in the form of environmental taxes, minus contributions like not using a car, using a small apartment, and so on. This design will be very progressive and practical. Alternatively, an ecotax can be designed as a "lifeline". Modest consumption is priced relatively low (even zero for water products), and higher consumption is priced higher [7,8].

The ecotax policy package may include revenue recycling to reduce or eliminate any regressions. The increase in ecotax is offset by a reduction in payroll (regressive) or consumption tax. Furthermore, the poor are frequently more keenly affected by pollution and other types of environmental degradation. These people cannot "buy a way out" when they become subject to air pollution, water pollution, etc. Therefore, by reducing environmental harm, such tools have a cumulative effect on this target group.

\subsection{Methodology}

\subsubsection{Analytical Model}

For each case, the report will consider whether or not an environmental tax is a successful policy within the specific policy context of the country in question and based on available data. We follow the analytical framework and the criteria used by OECD [9] to examine the implementation and evaluate the achievement and effectiveness of PET. Those measures are:

- $\quad$ Economic and fiscal impacts - includes the impact on GDP growth, tax revenues and national budget revenues, employment, industrial output, and inflation.

- Environmental effectiveness - did the tax reduce pollution (e.g., $\mathrm{CO}_{2}$ or other greenhouse gas emissions) or minimize energy consumption?

- Social impacts - includes impacts to household welfare resulting from changing relative prices, have implications for poverty.

Based on the primary and secondary sources of information, the article will analyze the inadequacies in the design and implementation of the current environmental tax. From there, propose solutions to improve the design and improve the efficiency of environmental tax enforcement towards sustainable development in Vietnam. This article will follow the analytical model as below (Figure 1):

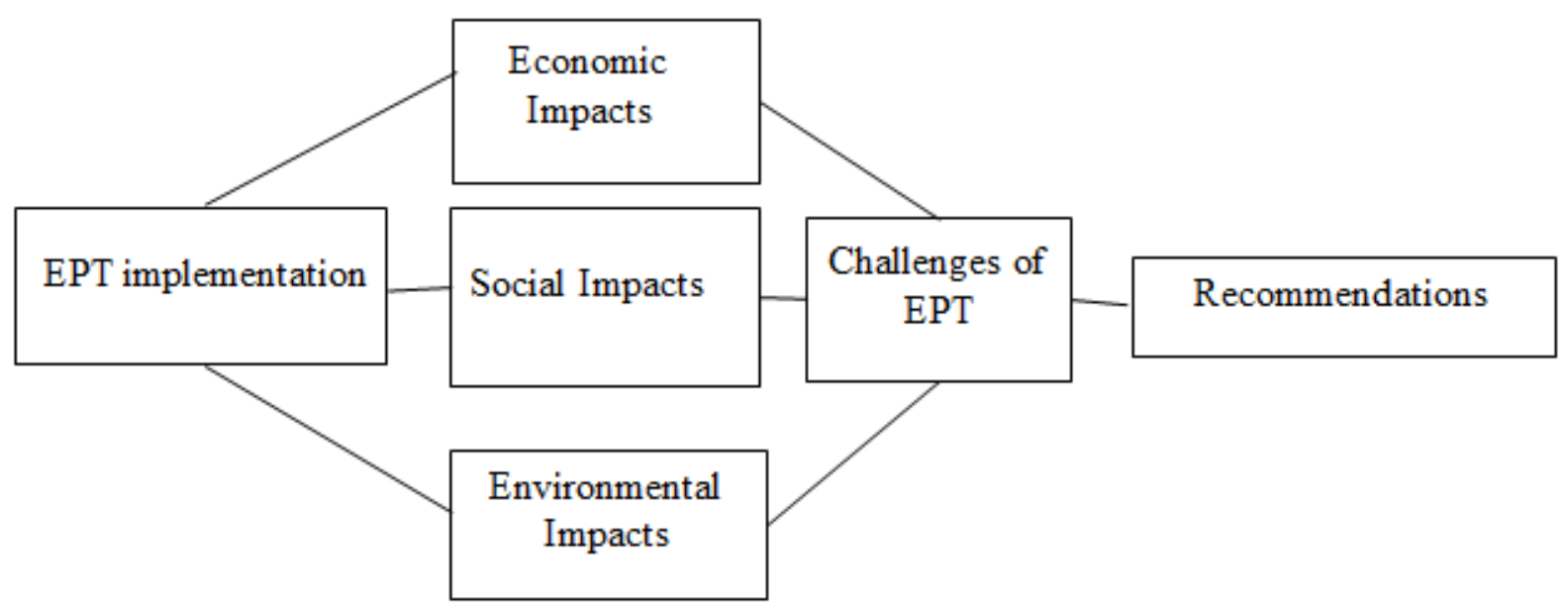

Figure 1. Analytical model of EPT in Vietnam 


\subsubsection{Data Collection}

It is not easy to find robust data on the impacts of environmental taxes. Extrapolating which changes are due to an environmental tax's direct and indirect effects on behavior and macro-economy is not simple [10, 12].

Therefore, the approach employed in this study consists of the examination of documents and information from various interviews with public authorities and specialists. The first step was to examine analytical reports from the specialists who worked on the problem. These publications originate from the World Bank (2017), the Institute of Finance Policy and Strategy (2016), the Government of Vietnam (2017), the Ministery for Finance (MOH) (2019), and the MONRE (2020).

In the second stage, all EPT effects and problems were recognized in the reports described above. Only texts adopted after 2010 were selected for the sake of coherence. Since the number of papers is still relevant, the most crucial ones are gathered through interviews with specialists and civil service officials.

Finally, the results of desk studies were compared with information obtained from field surveys conducted in tandem, which led to critical evaluations. The authors met and discussed EPT implementation with stakeholders and public servants in various sectors.

\section{Results}

\subsection{Situation of Environmental Protection Tax in \\ -}

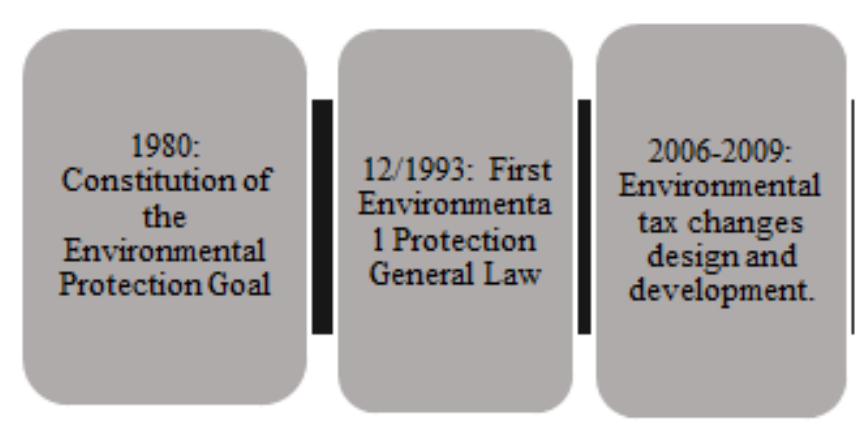

\section{Vietnam}

The mandate for the tax reform is an essential part of the broader environmental protection strategy pursued by the Vietnamese Government. It is firmly embedded in the existing framework of environmental protection legislation currently in force in Vietnam. The Environmental Protection Law of 1993 was revised when the Law of Environmental Protection of 2005 called for an environmental tax. In which "organizations, households, and individuals that produce and trade in certain types of products that cause long-term adverse impacts on the environment and human health must pay environmental tax" [13].

Under that clause, the Government, together with the applicable tax rate, was to submit to the approval of the National Assembly a register of items and commercial operations subject to the environment tax. Under this first requirement, this tax income would be utilized for a specific environmental protection purpose alone. It is not allocated in the State budget for other uses. Furthermore, the Environmental Protection Tax Act would govern all subjects involved in activities that produce ecological damage under the Tax Reform and Modernization Plan for 2005-2010. It depends on the premise that the taxable amount is equal to or above the level of harm to the environment [14]. The development timeline Vietnamese EPT was conceived from 1980 to 2010, as shown in Figure 2.

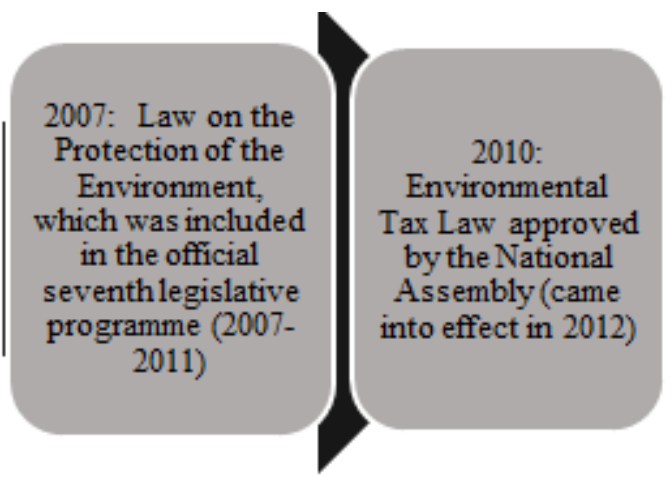

Figure 2. Vietnam's EPT development timeframe 
On November 15, 2010, the National Assembly passed the Law on Environmental Protection Tax, which took effect from January 1, 2012. The Law on Environmental Protection Tax has specific provisions on taxable objects, non-taxable objects, taxpayers, tax bases, tax declaration, tax calculation, tax payment, and environmental protection tax refund. As follows:

\section{Taxable Objects}

Article 3 of the Law on Environmental Protection Tax defines 08 groups of subjects subject to environmental protection tax as essential goods in life, including: (i) Gasoline, oil, grease and lubricants; (ii) coal; (iii) HCFC solution; (iv) plastic bags; (v) herbicides (restricted use); (vi) termiticide (limited use); (vii) forest product preservatives (limited use); and (viii) stock disinfectant (limited use). The selection of taxable objects with a degree of environmental impact in the initial implementation stage is appropriate and feasible. However, it needs to be studied for amendments and supplements to reflect the actual production and consumption of goods that pollute the environment [11].

In fact, in Clause 9, Article 3 of the Law on Environmental Protection, "In case it is deemed necessary to add other taxable objects to suit each period, the National Assembly Standing Committee shall consider and prescribe". However, since the Law on Environmental Protection. Since tax took effect, Vietnam has not yet adjusted the list of goods and services subject to environmental protection tax.

Currently, some goods are likely to cause environmental pollution when used but have not been included in the group of objects subject to environmental protection tax, such as batteries, accumulators, etc. There are 03 principles to ensure when conducting adding many other products causing environmental pollution to the taxable environment for environmental protection, specifically: (i) in line with international commitments to which Vietnam has joined and international practices; (ii) manufactured or imported goods that cause adverse impacts on the environment when used; (iii) ensure the feasibility and harmonization with economic development, especially without negatively affecting the competitiveness of domestic exports in the international market.

\section{Taxpayers}

Article 5 of the Law on Environmental Protection Tax defines taxpayers as organizations, households, and individuals engaged in producing and importing goods subject to environmental protection tax. Thus, the Law on Environmental Protection Tax in 2010 has added taxpayers who are importers of goods subject to environmental protection tax. The addition of this group of subjects solves the tax evasion loophole, thereby overcoming the limitations of the 2005 Environmental Protection Law.
Specifically, to evade environmental protection tax, instead of producing products that are harmful to the environment, the subject will import them to avoid paying this tax.

Environmental protection tax is an indirect tax to encourage consumers (polluters by using products harmful to the environment) to use environmentally friendly goods $[11,12]$. Therefore, consumers have to pay environmental protection tax because this tax has appropriately been calculated into the selling price of goods to avoid harsh reactions from consumers.

\section{Tax Bases}

Article 6 of the Environmental Protection Tax Act 2010 specifies the foundation for the tax computation. The foundation of the environmental tax calculation is the quantity of taxable items and the absolute tax rate. As follows, the amount of commodities is regulated: The number of goods produced for selling, exchanging, domestic use or donation is the amount of taxable goods; the number of goods imported and the absolute tax calculation rate set out in Article 8 of the Law for Environmental protection Tax is the amount of taxable goods. The number is the same as for imports. The amount of taxable goods is that of the goods.

The tax calculation method is the amount of environmental protection tax payable equal to the number of taxable goods units multiplied by the prescribed absolute tax rate per unit of goods.

\section{Tax Brackets and Tax Rates}

Under the legislation, the National Assembly set ranges for the tax rates (see Table 1). The legislative deliberations increased the lower range of the tax on coal from 6,000 to 10,000 VND per ton and shifted the tax range on plastic bags from 20-30,000 to 30-50,000 VND per kilogram. Interestingly enough, the National Assembly and many representatives to the regional meetings consistently supported the Law and often asked for even higher tax rates and a greater range of taxable objects, given the many environmental problems these objects cause.

According to Article 8 of the Environmental Protection Tax Act, and in line with along-standing Vietnamese tradition, the specific tax rates within the ranges are set by the National Assembly's Standing Committee. The following principles govern the choice of both current and future typical tax rates:

- Tax rates for taxable objects shall be in line with the socio-economic development.

- Tax rates for taxable objects shall be in line with the Government's socio-economic development policies for each period.

Applicable tax rates are set in the following manner: rates shall be adjusted every two to three years depending on the socio-economic circumstances prevailing in Vietnam, annually in the event of sufficient public support. 
Table 1. Ranges of tax rates

\begin{tabular}{|l|l|c|c|c|}
\hline & Taxable object & Unit & $\begin{array}{c}\text { Tax rate range } \\
\text { (VND/unit) }\end{array}$ & $\begin{array}{c}\text { Tax rate } 2012 / 13 \\
\text { (VND/unit) }\end{array}$ \\
\hline $\mathbf{1 .}$ & Gasoline, oil, grease & & 1,000 \\
1.3 & Gasoline (except ethanol) & Let fuel & $\begin{array}{c}\text { Litre } \\
1,000-4,000\end{array}$ & 1,000 \\
1.4 & Diesel & Litre & $1,000-3,000$ & 500 \\
1.5 & Paraffin & Litre & $500-2,000$ & 300 \\
1.6 & Mazut & Litre & $300-2,000$ & 300 \\
1.7 & Lubricating oil & Litre & $300-2,000$ & 300 \\
1.8 & Grease & $\mathrm{Kg}$ & $300-2,000$ & 300 \\
\hline $\mathbf{2 .}$ & Coal & Ton & $10,000-30,000$ & 10,000 \\
2.1 & Lignite & Ton & $20,000-50,000$ & 20,000 \\
2.2 & Anthracite coal & Ton & $10,000-30,000$ & 10,000 \\
2.3 & Fat coal & Ton & $10,000-30,000$ & 10,000 \\
2.4 & Other types of coal & $\mathrm{Kg}$ & $1,000-5,000$ & 4,000 \\
\hline $\mathbf{3 .}$ & Hydro chlorofluorocarbons (HCFC) & $\mathrm{Kg}$ & $30,000-50,000$ & 40,000 \\
\hline $\mathbf{4 .}$ & Taxable soft plastic bags & $\mathrm{Kg}$ & $500-2,000$ & 500 \\
\hline $\mathbf{5 .}$ & Herbicides restricted in use & $\mathrm{Kg}$ & $1,000-3,000$ & 1,000 \\
\hline $\mathbf{6 .}$ & Pesticides restricted in use & $\mathrm{Kg}$ & $1,000-3,000$ & 1,000 \\
\hline $\mathbf{7 .}$ & Forest product preservatives restricted in use & $\mathrm{Kg}$ & $1,000-3,000$ & 1,000 \\
\hline $\mathbf{8 .}$ & Warehouse disinfectants restricted in use & & \\
\hline
\end{tabular}

Tax Declaration, Tax Calculation, and Tax Payment

The tax declaration, tax calculation, and tax payment of environmental protection tax for goods produced for sale, exchange, internal consumption, or donation are carried out monthly according to the Law on tax administration provisions. The tax declaration, tax calculation, and payment of environmental protection tax for imported goods are made simultaneously as the tax declaration and import tax.

Environmental protection tax is paid only once for manufactured or imported goods and remitted into the state budget at the State Treasury, at the tax administration agency where the tax declaration dossier is received. It must be through an organization authorized by the tax management agency, tax collection agency, commercial banks, other credit institutions, and service organizations as prescribed by Law. The proceeds are fully accounted into the state budget and spent on socio-economic development tasks under the provisions of the State Budget Law.

\section{Tax Refund}

Article 11 of the Law on Environmental Protection Tax in 2010 stipulates that environmental protection taxpayers are entitled to a refund of paid tax in specific cases in a reasonable manner, ensuring the interests of taxpayers. However, the Law has not paid attention to tax incentives such as exemption and reduction of environmental protection tax.

Meanwhile, applying tax incentives contributes to promoting production organizations and individuals to be more conscious in limiting the negative impacts of production activities on the environment. In addition, these entities will reduce the discharge of hazardous substances into the environment by applying advanced production technologies, producing more environmentally friendly goods through promoting clean technology applications.

\subsection{Environmental Protection Tax Impacts and Efficiency}

\subsubsection{Economics Impacts and Efficiency}

After eight years of implementation, the environmental protection tax itself has contributed to a significant increase in state budget revenue, contributing to the performance of the country's socio-economic tasks, including spending on environmental protection.

Specifically, the revenue from environmental protection tax has continuously increased steadily from 2012 up to now. Statistics show that the amount of environmental protection tax in 2012 was about 11,676 billion VND; 2013 was about 11,849 billion VND; 2014 was about 12,087 billion VND; 2015 is about 27,020 billion VND; 2016 is about 43,142 billion VND; 2017 is about 44,825 billion VND; in 2018 is 47,050 billion VND and in 2019 is 63,079 billion VND. The ratio of environmental protection tax to total state budget revenue has increased from more than $1 \%$ to nearly $5 \%$ (in 2019, it was 4.92\%) [10]. In particular, the amount of environmental protection tax revenue from the group of petroleum, coal accounted for the majority (about 99\%) of the total environmental protection tax [15]. From 2012 to 2019, the revenue from environmental protection tax has increased, as shown in Figure 3. 


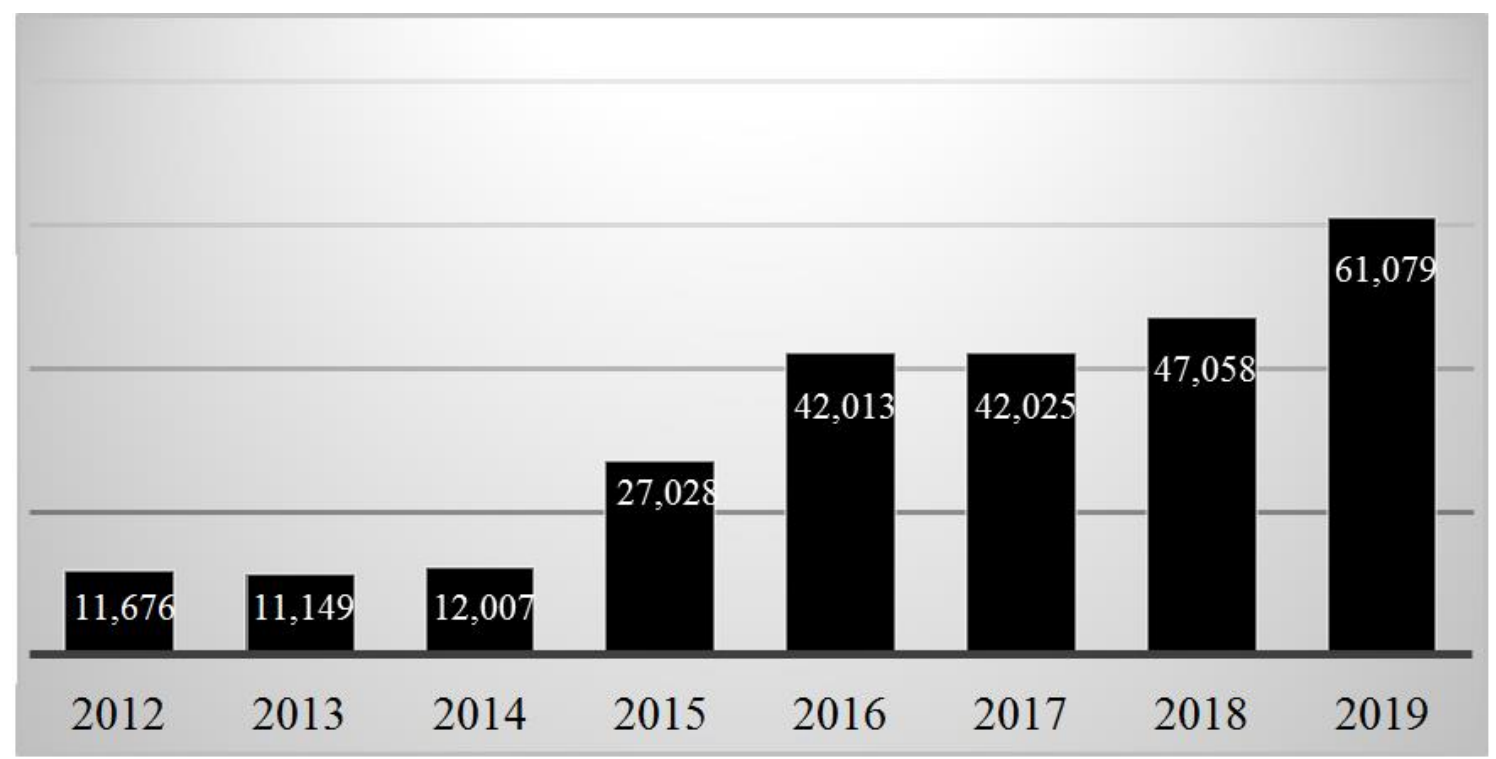

Figure 3. Revenue from environmental protection tax in the period 2012-2019

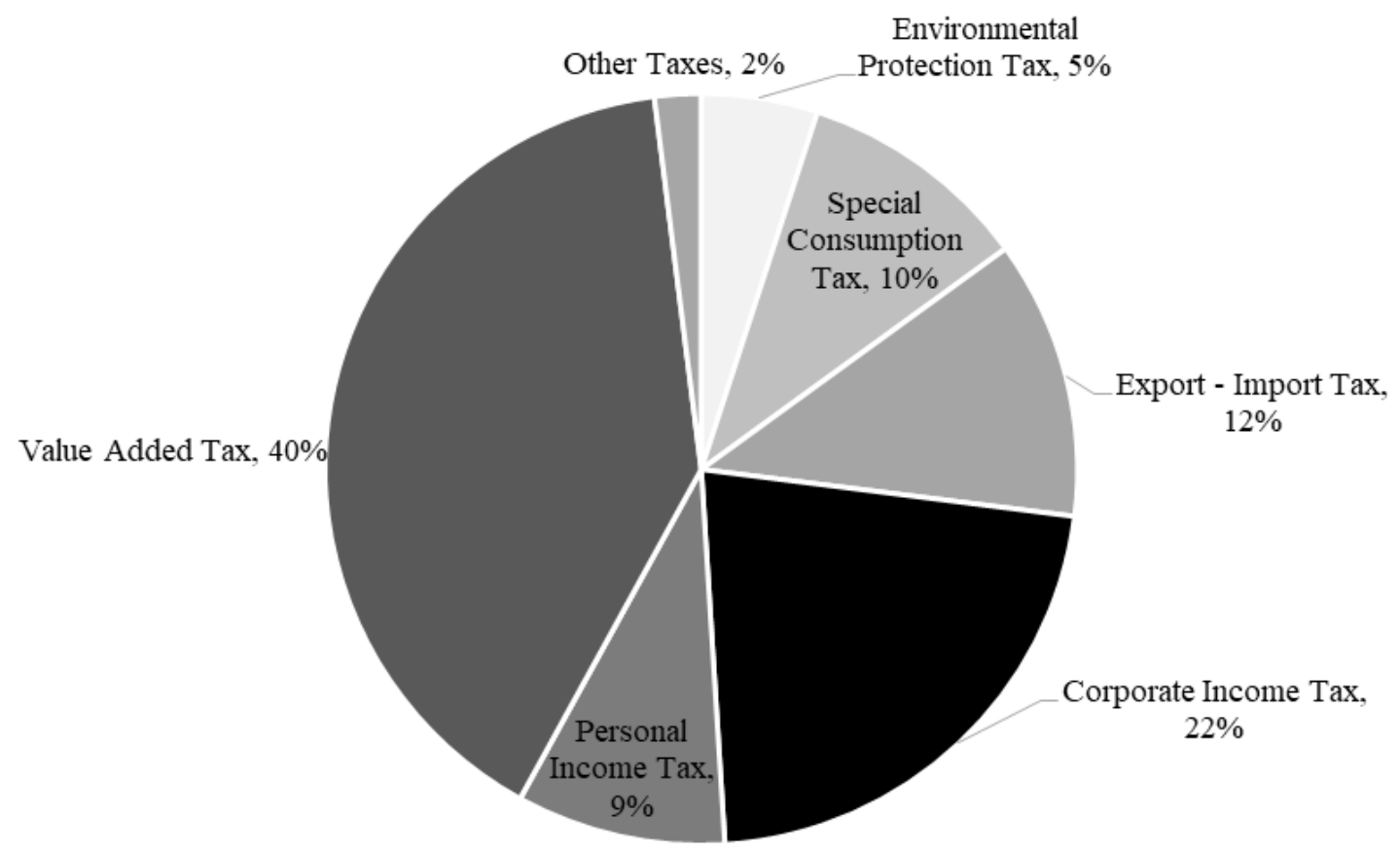

Figure 4. The tax system in Vietnam as of October 2018

Environmental protection tax is not a countervailing revenue. It is directly refunded, not used for specific spending tasks but to perform general spending tasks under the State Budget Law and approved by the National Assembly annually. With the average collection of environmental protection tax in 2012-2019 reaching about 32,600 billion $\mathrm{VND} /$ year, it has contributed to increasing state budget revenue to carry out socio-economic tasks of the country, including spending on environmental protection. Details of the percentage of tax in Vietnam till 2018 have been shown in Figure 4.
Impact on the Macroeconomy

A computable general equilibrium (CGE) implemented by $A+B[5,8]$ reveals some economic impacts of EPT implementation in Vietnam. According to the model, the EPT will lower GDP growth by $-0.8 \%$ in the short run and between $-0.05 \%$ and $-0.36 \%$ in the long run, depending on labor market closure. The inflation rate rises as well, with the CPI growth rate increasing by $0.4-0.7$ percent [16].

The environmental tax must be levied on the intermediate and final domestic use of coal and refined fuels for sectoral effects. Taxation is applied to 
domestically and imported coal and fuel. The immediate effects of these commodities are an increase in the user price [17]. In terms of manufacturing, higher prices for taxed items induce the impact of substitution among energy inputs, change the production costs, and thus the supply price of locally manufactured goods. The six fuel-intense industries most affected by tax hikes in the input prices are illustrated in Figure 5.

Table 2 illustrates the effect of EPT on real output on chosen sectors in the economy, which are highly affected. According to the results, the fuel tax poses a serious danger to the viability of small refineries in Vietnam. The increase in refined fuel costs, as we have seen, demands a compensatory increase in the pricing of domestic manufacturers that makes the industry uncompetitive for imports. As a result of taxation, the government claims a greater proportion of production resources. The growth in actual public spending (which indicates an increase in domestic demand for non-tradable goods and services) increases the price of non-tradable commodities concerning export products, therefore discouraging the export of goods and exports. There is hence a decrease in exports [15].

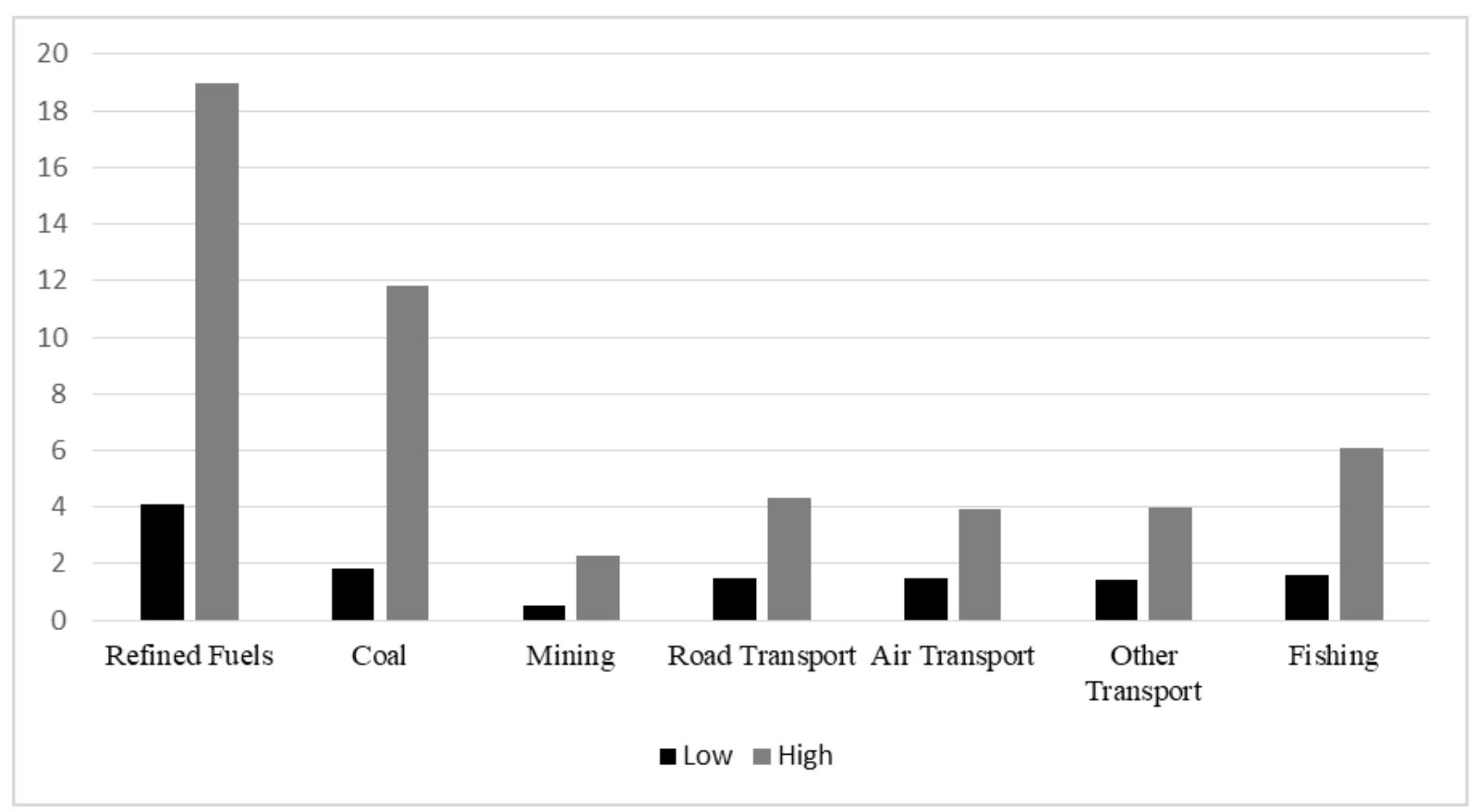

Figure 5. Sectoral User Price Impact (\% relative to Consumer Price Index)

Table 2. Impact on Real Output by Sector (\%)

\begin{tabular}{|l|c|c|c|}
\hline & Base level 2007 & Low & -98.8 \\
\hline Refined Fuels & 2.795 & -87.3 & -10.8 \\
\hline Coal & 23.196 & -2.5 & -4.7 \\
\hline Road Transport & 60.092 & -1.2 & -21.2 \\
\hline Air Transport & 8.436 & -5.9 & -3.6 \\
\hline Other Transport & 20.823 & -0.9 & -7.4 \\
\hline Fishery & 26.410 & -1.8 & -11.6 \\
\hline Fish processing & 69.441 & -2.8 & -3.9 \\
\hline Aquaculture & 55.887 & -0.9 & 11.1 \\
\hline Textiles and Clothing & 168.903 & 2.5 & \\
\hline
\end{tabular}


The introduction of the EPT also has an impact on wages and jobs. Actual earnings remain consistent shortly, but the taxes lower wages and other factors in the long run. The salaries of skilled laborers are falling at a faster rate in rural and urban regions, reflecting the proportionate drop in activity in the industrial and services industries that are more qualified. Furthermore, the loss of untrained employment decreases demand for expert employees whose nominal salaries decrease by about $-3 \%$.

\subsubsection{Environmental Impacts and Efficiency}

There is an evidence of behavioral reactions to the tax in terms of environmental efficiency. $\mathrm{CO}_{2}$ emissions are expected to grow from 247 million tons of $\mathrm{CO}_{2} \mathrm{e}$ in 2010 to close to 800 million tons of carbon dioxide, and also almost 2030 under a business as usual scenario [15]. Stable tax returns in the first phase of the 2012-2014 tax indicate the relative stability of transport fuel use - representing at least $90 \%$ of total income. Subsequent revenue growth was due to higher tax rates and not increases in the usage of transport fuel. It shows that the EPT was slowing the rapid increase in transport fuel use and consequently the growth of transport sector emissions, creating drivers for behavioral change. GIZ commissioned $[10,11,12]$ modeling that indicates that a drop of around 1.7 percent resulted in reductions in $\mathrm{CO}_{2}$ emissions by about two million tons during 2012 and 2013. Further tax hikes in 2015 and 2018 might have greater consequences for $\mathrm{CO}_{2}$ emissions by modeling the yearly decrease in $\mathrm{CO}_{2}$ emissions of over 9 million tons or $7.9 \%$ in a tax scenario of higher quality [14].

Table 3. Estimated changes in aggregate industrial pollution (\%)

\begin{tabular}{|c|c|c|c|}
\hline & $\begin{array}{c}\text { Short-run: } \\
\text { fixed wages, } \\
\text { flexible } \\
\text { employment }\end{array}$ & $\begin{array}{c}\text { Medium-run: } \\
\text { Full } \\
\text { employment, } \\
\text { flexible wages }\end{array}$ & $\begin{array}{c}\text { Medium-run: } \\
\text { flexible } \\
\text { employment of } \\
\text { unskilled } \\
\text { workers }\end{array}$ \\
\hline $\begin{array}{c}\text { Air } \\
\text { pollution }\end{array}$ & -0.94 & -0.32 & -0.55 \\
\hline $\begin{array}{c}\text { Solid } \\
\text { waste }\end{array}$ & -0.8 & -0.30 & -0.48 \\
\hline $\begin{array}{c}\text { Water } \\
\text { pollution }\end{array}$ & -0.73 & -0.33 & -0.49 \\
\hline $\begin{array}{c}\text { Total } \\
\text { emissions }\end{array}$ & -0.85 & -0.31 & -0.51 \\
\hline
\end{tabular}

There is also a discussion of the good influence of environmental levies. The findings of the overall equilibrium model reveal a considerable comparable drop from $-0.73 \%$ to $-0.94 \%$ in air, water, and solid waste emissions in the near term, with a significantly negative change in GDP. In the longer term, the reductions in emissions are the same pattern as the decreases in GDP, as indicated in table 3 when the labor market adjustment occurs. Emissions reductions are just around $-0,3 \%$ in full employment, a flexible wage closure. The reductions are slightly greater, at $-0.5 \%$, given the flexible hiring of unqualified individuals. However, it is important to note that these statistics indicate a decline in the growth rate of the carbon emissions, rather than the decline in absolute emissions levels, as with the other data provided from those simulation trials.

EPT contributes to the implementation of Vietnam's commitment to the international community on environmental protection.

Vietnam has been actively integrating internationally in the environment by participating in many international commitments on environmental protection. The promulgated environmental protection tax policy has demonstrated the vigorous efforts of the Vietnamese Government in implementing international commitments in environmental protection.

The Kyoto Protocol on greenhouse gas emission control, to which Vietnam is a member, took an effect on February 16, 2005, in which Vietnam committed to implementing the "Clean Development Mechanism" (CDM) in the sectors: energy, industry, transportation, agriculture, forestry, and waste management... With the introduction of products such as gasoline, oil, grease, coal, HCFC solution into taxable objects, Environmental protection has demonstrated Vietnam's efforts in implementing CDM commitments, thereby improving the efficiency in receiving financial support and transferring new technologies from developed countries participating in the Kyoto Protocol through CDM projects, as well as towards sustainable socio-economic development.

The Montreal Protocol on Substances that Deplete the Ozone Layer is an international treaty of the Vienna Convention designed to protect the ozone layer by phasing out the production of substances, including HCFCs, which is is believed to be responsible for the depletion of the ozone layer. Vietnam commits to complete the elimination of the HCFC solution by 2030. The introduction of the HCFC solution into the subject of environmental protection tax will contribute positively to Vietnam to eliminate HCFCs as committed.

In addition, at present, Vietnam has actively participated in other multilateral conventions and treaties on environmental protection. For example, the Ramsar Convention on Wetlands of International Importance in 1989, The UN Framework Convention on Climate Change 1992, UN Sea Law Convention, 1994 Convention on Biodiversity, and Development of the Declaration on Environmental Protection in Rio, Global Agenda 21; The 1999 International Cleaner Production Declaration [16].

The Viet Namese NDC12, published by UNFCCC under the Paris Agreement, pledges Viet Nam to $8 \% \mathrm{CO}_{2}$ emissions reduction in comparison to the 2021 and 2030 business-as-usual (BAU)[18]. Vietnam's nationally determined contribution(NDC) Given that Vietnam plans to reduce 8 percent in emissions from 474.1 million $\mathrm{tCO}_{2} \mathrm{e}$ in 2020 to 787.4 million $\mathrm{tCO}_{2} \mathrm{e}$ in 2030, the BAU is still an absolute rise of 288 million $\mathrm{tCO}_{2} \mathrm{e}$ [15]. The NDC promises reductions in emissions of $\mathrm{BAU}$ up to 25 percent with 
international help. Even this increase would lead to 235 million $\mathrm{tCO}_{2} \mathrm{e}$ rising greenhouse gas (GHG) emissions.

While achieving these NDC commitments will not lead to absolute emission cuts, it will slow down the present fast GHG increase. Commitments such as these, along with a large number of national policy papers - decrees, laws, and circulars - all indicate Vietnam's degree of responsibility to integrate environmental policies with other growth stimuli, economic restructuring, energy safety concerns, and access to international financing (particularly climate finance). Therefore, environmental improvements are incorporated in Vietnam as a co-benefit of policies to achieve other objectives in various policy-making sectors. The adoption of environmental taxes has unavoidably affected the surrounding environment, social equality, and the entire economy.

\subsubsection{Social Impacts and Efficiency}

\section{Impact on Household Income}

The entire price increases because of the overall effects of energy costs. Higher consumer goods prices lower the buying power or real income of the household. The changes in employment, salaries, and returns on land and capital also impact household incomes. The drop in private consumption would be increased if the government did not reverse some of the tax revenues through transferring money or reducing taxes to households $[11,19]$.

The EPT directly influences actual income in nearly every kind of family (unemployed households depend mainly on transfers and are less affected, but as the first column of data reveals, they are tiny groups within the total population). Urban households suffer the most severe losses. The long-term differences between rural and urban homes of comparable types are reduced when employees migrate between urban and rural areas [20].
The key point is that the reform of taxation would entail significant economic consequences at the high end of the proposed tax interval - if the move to the high end of the tax band is linked to tax rates increase in actual terms. Suppose the refined liquid fuel tax rates are to be realized. In this scenario, the tax hikes should be gradually phased in with a transparent schedule for projects with greater energy efficiency $[10,11]$.

\section{Impact on Poverty}

The total effect of the EPT on poverty was also identified by the mapping of the VHLSS domestic database modifications from the simulation model. In each of these poverty indicators, Table 4 shows percentage changes. In the near term, with each step, poverty increases rapidly. The poverty rate of the leading population is rising by $3.4 \%$, the poverty gap by $3.8 \%$, and the square poverty gap of $4.2 \%$, suggesting that the poorest families are in the near term also the largest losers [21]. Generally, changes are far less than anticipated once the job market has adjusted in the long term. There is one aspect in the table of interest: various poverty metrics exhibit long-term, differing results. The measure on the headcount reveals that urban poverty and rural poverty are falling significantly.

The poverty gap and the squared gap measurements, by contrast, suggest that rural families are less impacted than urban ones. The considerable decrease in the measurement of the city headcount implies a greater density of families divided by the poverty line. However, the gaps indicate a different narrative, with small decreases in poverty, largely focused on the rural population. The following table is divided into three periods: The following: Short-runs: fixed pay, flexible employment; medium-runs: full employment, versatile salaries; medium-runs: versatile employment.

Table 4. Poverty changes in the medium run (\% change from the base, after transfers)

\begin{tabular}{|c|c|c|c|}
\hline & Short-run & Medium-run & Medium-run \\
\hline Headcount: Total & 3.41 & 0.13 & -0.16 \\
Urban & 1.87 & -2.48 & -2.60 \\
Rural & 3.68 & 0.60 & -0.28 \\
\hline Poverty gap: Total & 3.79 & -0.12 & -0.33 \\
Urban & 4.52 & -0.43 & -05 \\
Rural & 3.68 & -0.08 & -0.39 \\
\hline Squared poverty gap: Total & 4.18 & -0.17 & -0.48 \\
Urban & 6.59 & 0.44 & 0.78 \\
\hline
\end{tabular}




\subsection{Challenges in Implementation of Environmental Protection Tax in Vietnam}

In addition to the achieved results, implementing the environmental protection tax policy is still complex. It is necessary to continue researching to perfect it by reality, specifically as follows:

Firstly, about taxpayers, the Law on Environmental Protection Tax lists eight groups of subjects subject to environmental tax. Many products and goods whose use is likely to cause environmental pollution have not been included in the Law on Environmental Protection Tax regulation. It can be seen that in 2012 when the Law on Environmental Protection Tax was applied for the first time in Vietnam, the drafters selected the most recognizable groups to have clear and transparent management measures. Therefore, in the list of taxable objects, many harmful substances such as tobacco, chemicals (including inorganic acids, caustic soda, plant protection chemicals, organic solvents, etc.) mechanics, mercury, detergents, etc.); electronics (generating e-waste); rubber (tubes, tires, etc.); polymer.

Second, problems arise when designing and using absolute tax brackets. In 2010, to ensure stability in tax collection management, the Law established minimum and maximum absolute tax rates. It was built based on the degree of negative impact on the environment. Also, it had an inheritance of the tax collection policy applicable for petrol and oil fees and environmental protection fees. However, according to the tax bracket in Article 8 of the Law on Environmental Protection Tax, the persuasiveness of the absolute tax rate for some taxable objects is still not high. For example, the tax rate for taxable plastic bags is from 30,000 to $50,000 \mathrm{VND} / \mathrm{kg}$. The regulation of this tax rate is low and has little impact on reducing the use of plastic bags, even the use of plastic bags increases in 2012-2020. In addition, the tax rate range (minimum to maximum) for taxable objects is too broad. For example, the tax rate for coal is from 10,000 to $50,000 \mathrm{VND} / \mathrm{ton}$, and gasoline, oil, and grease is from $300-4,000 \mathrm{VND} /$ liter. It leads to the possibility of inconsistent application to the same product in different localities.

Third, the basis for calculating environmental protection tax is taxable goods and the absolute tax rate. Regulations on the number of taxable goods are still sketchy. There are no specific regulations on the method of determining the number of taxable goods in the following cases: the number of taxable goods cannot be determined (the tax authority is allowed to determine the quantity according to the criteria and level); in case products are bought and sold through many stages such as purchasing and collecting (how to determine taxable output at each phase); in case products are used to produce other products in the same enterprise (coal mining for electricity production).

Fourth, the regulations on the framework and rates of environmental protection tax for taxable goods are not yet consistent with the level of environmental pollution of these goods. According to the provisions of the Law on Environmental Protection Tax, the principles for determining the framework and rate of environmental protection tax for taxable goods is the degree of adverse impact on the environment of the goods subject to tax and the socio-economic policy development of the State in each period. Currently, the tax is contrary to this principle when it is collected at the absolute tax rate, while the tax rate should be determined based on the content of toxic substances in the goods. In addition, the tax rate is not reasonable among taxpayers. For example, the level of adverse impact on the environment of fuels is different but subject to the same tax rate, thereby causing harm to the environment. Therefore, those who drive environmental damage will be subject to a relatively lower tax rate. In addition, the difficulty of controlling inflation in Vietnam requires the tax calculation framework and absolute tax rate to change continuously. In fact, since 2010, the tax calculation frame has remained almost unchanged. Only the absolute tax rate has changed for petrol and oil (increasing from 1,000 VND/liter in 2012 to 3,000 $\mathrm{VND} /$ liter in 2016 and 40,000 VND/liter in 2018).

Fifth, the regulation on the time of calculation of environmental protection tax for imported petrol and oil for sale is when petrol and oil trading hubs sell, leading to difficulties in management and tax declaration and payment. This regulation quickly leads businesses to take advantage of the import of petroleum but not sell it but only use it for production, which can lead to loss of budget revenue. In addition, the above regulations are not consistent with rules on tax declaration and payment of environmental protection tax for other goods subject to environmental protection tax imported. Implementing the 2015 State Budget Law (effective from the 2017 budget year) is not convenient that the environmental protection tax collected from imported goods is a $100 \%$ central budget revenue. Therefore, it is necessary to amend the regulations on calculating environmental protection tax for petrol and oil accordingly.

Sixth, there is an imbalance in revenues and expenditures for environmental protection. According to a report of the Ministry of Finance (2010) [15], in the period 2015-2019, revenue from EPT increased four times, but spending on environmental protection increased by less than 1.4 times. The environmental protection tax ceiling has increased sharply, especially for petroleum, but the actual spending rate for this purpose has been decreasing in the past five years.

The Law on Environmental Protection Tax lacks the vital content of managing and using the proceeds from environmental taxes. According to Article 9 of Circular No. 152/2011/TT-BTC dated 11-11-2011 guiding the implementation of many items of the Law on Environmental Protection Tax, the state budget allocation for tax revenues environmental protection shall comply with regulations of competent state agencies. It is a general 
provision that can make people skeptical about the environmental protection effectiveness of this Law. Experience shows that the money collected from EPT should only be used to protect and remediate environmental pollution.

\section{Recommendations}

Firstly, on taxable objects, regulations on taxable objects must cover all products and goods that negatively impact the environment. This Law has not been able to do. However, after applying the Law, it is possible to consider and select taxpayers suitable to the level of development and the economy's tolerance. The inclusion of a product to the taxable status of a product must also consider the feasibility of the manufacturer, the management agency, and the Law's feasibility. Moreover, the taxation must also consider the tolerance of producers and consumers, taking into account the benefits in choosing between environmental protection and economic development.

In the current conditions of our country, only products that affect the environment should be selected on a large scale and determine a reasonable tax rate, ensuring the competitiveness of the economy and the consumption capacity of the citizen. Many products pollute the environment when used and disposed of, but the degree of pollution is different. It is necessary to review the list of goods, investigate more practices, and add taxable objects to ensure the inclusiveness and fairness of the regulations on taxable objects. This implementation must be based on the principle that any product that negatively impacts the environment must be subject to tax. For products with low impact or polluting goods but need support to ensure competitiveness, a low tax rate can be applied in the immediate future to deal with the problem flexibly in some necessary cases, avoiding the need to amend and supplement ensure the stability of the Law.

Secondly, the basis for calculating environmental protection tax is taxable goods and the absolute tax rate. Regulations on the number of taxable goods are sketchy. Regarding the method of determining the number of taxable goods, to create a clear basis in the implementation organization, it is necessary to specify the process of determining the number of taxable goods in the following cases: it is not possible to specify the number of taxable goods; products are bought and sold through many stages such as collection (determine taxable output at each stage); products used to produce other products in the same enterprise [22, 23].

Third, based on the tax rate bracket, determining the environmental protection tax rate is a core and complex issue, based on strict scientific arguments and relevant practical grounds. However, it can be seen that the criteria for building a tax rate bracket for some taxable objects as in the Law on Environmental Protection Tax are not enough practical grounds, so the convincingness is not high. Determining the tax rate bracket for some commodities, such as gasoline, oil, and coal, based on the environmental protection fee is not reasonable because the regulatory nature of the two tools is different [23]. On the other hand, environmental protection fees determine specific collection rates, but environmental protection taxes stipulate a tax rate bracket. Therefore, for the persuasive provisions of the Law, it is necessary to clearly explain the tax bases, socio-economic impacts, and the degree of environmental pollution for each item based on scientific arguments. Also, it is essential to provide specific evidence, avoid applying subjective tax rates, and ensure fairness in using policies.

Fourth, on the authority to determine tax rates in the tax rate bracket, according to regulations, the National Assembly shall prescribe the tax rate bracket, and the Standing Committee of the National Assembly will prescribe specific tax rates. The assignment of the Standing Committee of the National Assembly to stipulate typical tax rates is reasonable, ensuring flexibility in management, in line with fluctuations in unstable economic conditions [15]. However, the Law on Environmental Protection Tax should not stipulate a tax rate bracket. Still, it is necessary to specify a specific tax rate right in the Law to ensure the principle of tax rates decided by the National Assembly for stable application. For some special products such as petrol, oil, and coal, the goal is to ensure that the implementation schedule is suitable for price fluctuations and meet international commitments' implementation. To meet that goal, the tax rate bracket can be specified and assigned to the Standing Committee of the National Assembly to decide tax rates in each period.

Fifth, the tax rate bracket regulation is too broad for most groups of goods and commodities. It is necessary to subdivide groups of goods and have different tax rates for each item. A wide margin can be specified for goods subject to large price fluctuations, while a narrower band may be required for other commodities [24].

Sixth, the analysis suggests that higher actual tax rates for fuels should be phased in gradually according to a transparent pre - announced schedule to allow firms to plan investments in fuel - efficient technologies. In addition, measures are needed to facilitate the transition to low-carbon technology. The proposed tariffs increase the price of refined oil relative to the price of coal. The relationship of the coal tax rate to the fuel tax rate should be reviewed to avoid possible undesirable substitution effects for "refined, clean fuels" and "dirty coal" products.

\section{Conclusions}

The Environmental Tax Act in Vietnam represents a typical example of Environmental Taxation in developing nations because it covers a broad set of environmental contaminants. The tax design makes it easier to alter. The 
Modeling shows that in comparison to BAU, GDP growth and employment might have had some negative effects on the EPT. However, considering that total GDP growth in 2015-2025 has grown by 6\% yearly. Also, that employment at the same time has increased by $1 \%$. These modest effects are being offset by good improvements in the economy as a whole. The EPT seems to negatively influence social justice, with more EPT money generated by the poor in overall incomes. Even a little drop in household revenue can affect the quality of life and capacity for basic goods and services for households below or below the poverty line. While data on the magnitude of such effects are not available, increasing tax rates will need policymakers to pay greater attention to their effects on equality and guarantee targeted social offsetting.

In this research, environmental taxation was demonstrated as a cost-efficient tool for enhancing environmental standards and reducing pollution in Vietnam on human health. Therefore environmental taxation can result in environmental improvements while also complying with social equality and tax justice standards if carefully structured, considering both environmental consequences and equity impacts. Environmental taxes can assist nations in fulfilling their responsibilities to the environment, as enshrined in the UNFCCC, the Paris Agreement, and in the 2030 agenda, through international environmental treaties.

Regarding recommendations, the promulgation and application of the Law on Environmental Protection Tax must create an effective macro-management tool. This tool must identify and ensure the implementation of responsibilities of organizations and individuals that have negative impacts on the environment; raising people's awareness in the performance of environmental protection obligations; minimize the impact of production and business on the environment. The provisions of the Law must be suitable to the economic development of Vietnam. On the one hand, they must reasonably mobilize revenue for overcoming environmental consequences. On the other hand, they also must ensure the competitiveness of the investment environment, stabilize the market, prices, and curb inflation. Also, they must not disturb domestic production and business, not increase the financial burden on consumers, but ensure harmony between the interests of the Government with the people. It must be put in overall relationship with relevant provisions of Law, ensuring the consistency and synchronism of the whole system, in line with international practices and ensuring the implementation of international commitments.

\section{Acknowledgements}

This study is implemented with support from the National Economics University, Vietnam.

\section{REFERENCES}

[1] Jacqueline Cottrell, Tatiana, Falcão, “A Climate of Fairness: Environment Taxation and Tax Justice in Developing Countries" in Vienna Institute for International Dialogue and Cooperation Discussion Papers, 2018, pp. 56-103.

[2] Coxhead, Ian, Anan Wattanakuljarus, and Chan V. Nguyen, "Are Carbon Taxes Good for the Poor? A General Equilibrium Analysis for Vietnam" in World Development, pp. 119-200, 2016.http://www.sciencedirect.com/science/ar ticle/pii/S0305750X13001344 (accessed on May 19, 2016).

[3] Carnahan, M, "Tax Challenges in Developing Countries", Asia and the Pacific policy studies, Volume 2, issue 1, pp. 169-182, 2015. https://doi.org/10.1002/app5.70.

[4] Dixon, Peter B., and Maureen T. Rimmer, "Johansen's legacy to CGE modeling: Originator and guiding light for 50 years", World Scientific Reference on Asia-Pacific Trade Policies, pp. 459-479, 2020. https://doi.org/10.1142/9 789813274754_0016.

[5] Flues, F.and Thomas, A., "The distributional effects of energy taxes", OECD Taxation Working Papers No. 23, OECD, Paris, 2015, http://d.doi.org/10.1787/5js1qwkqqrbven.

[6] Flues, F. and K. van Dender, "The impact of energy taxes on the affordability of domestic energy", OECD Taxation Working Papers, No. 30, OECD Publishing, Paris, 2017, http://dx.doi.org/10.1787/08705547-en.

[7] Arlinghaus, J. and van Dender, K, "The environmental tax and subsidy reform in Mexico", OECD Taxation Working Papers, No. 31, OECD Publishing, Paris, 2017, http://dx.doi.org/10.1787/a9204f40-en.

[8] OECD, "The environmental tax and subsidy reform in Mexico", OECD Taxation Working Papers, No. 31, OECD Publishing, Paris, 2017, http://dx.doi.org/10.1787/a9204f40en.

[9] OECD, "OECD Economic Surveys: Mexico", OECD Publishing, Paris, 2017, http://dx.doi.org/10.1787/eco_surve ys-mex-2017-en.

[10] Bhattarai, Keshab \& Haughton, Jonathan \& Head, Michael \& Tuerck, David, "Simulating Corporate Income Tax Reform Proposals with a Dynamic CGE Model" in International Journal of Economics and Finance, Vol. 9, no. 20, 2017. https://doi.org/10.5539/ijef.v9n5p20.

[11] Bhattarai, Keshab \& Nguyen, Dung \& Nguyen, Chan., "Impacts of Direct and Indirect Tax Reforms in Vietnam: A CGE Analysis" in Economies, Vol. 7, no. 50, 2019. https://doi.org/10.3390/economies7020050.

[12] Dung, Nguyen Tien, "Macroeconomic Impacts and Redistribution of increasing VAT: A CGE Analysis", Hanoi: Vietnam Institute for Economic and Policy Research, VEPR, (In Vietnamese), 2018.

[13] Willenbockel, Dirk, "Environmental tax reform in Vietnam: An ex ante general equilibrium assessment", Paper presented at EcoMod2011 Conference, Azores, Portugal, June 29-July $1,2011$. 
[14] General Statistics Office of Vietnam (GSO), "Economic and Social Overview of Vietnam 2020", https://www.gso.gov.vn /default.aspx?tabid=382\&idmid=2\&ItemID=19041 (accessed on October 26, 2020).

[15] Do, N. D, "Inflation Perspective in Vietnam for Period 2018-2020", Journal of Finance, 2018, https:/tapchitaichinh .vn/nghien-cuu-trao-doi/trao-doi-binh-luan/trien-vong-lam-p hat-o-viet-nam-giai-doan-20182020-135413.html (accessed on January 12, 2019).

[16] Huong, Nguyen Thi, “Analyzing the Impact of Tax Policy on the Sectoral Structure of Vietnam Economy", Ph.D. thesis, The University of Danang, Da Nang, Vietnam, 2018.

[17] Maliszewska, Maryla, Zoryana Olekseyuk, and Israel Osorio-Rodarte, "Economic and Distributional Impacts of Comprehensive and Progressive Agreement for Trans-Pacific Partnership: The Case of Vietnam", 2018, http://documents.worldbank.org/curated/en/5300715205167 50941/Economic-and-distributional-impacts-of-comprehens ive-and-progressive-agreement-for-trans-pacific-partnership -the-case-of-Vietnam (accessed on October 23, 2018).

[18] OECD, "Effective Carbon Rates 2018: Pricing carbon emissions through taxes and emissions trading", OECD, Paris, 2018, https://read.oecd-ilibrary.org/taxation/effectivecarbon-rates-2018_9789264305304-en\#page1.

[19] UNU-WIDER, “World Income Inequality Database
(WIID3.4)", 2017, https://www.wider.unu.edu/database/wor ld-income-inequality-database-wiid34 (accessed on October $26,2018)$.

[20] Tan, P.T, "The Impact of the Global Financial Crisis on Vietnamese Economy", APRACA News, 2017, https://apraca.org/the-impact-of-the-global-financial-crisis-o n-vietnamese-economy/ (accessed on January 12, 2019).

[21]Minor, Peter, Terrie Walmsley, and Anna Strutt, "State-owned enterprise reform in Vietnam: A dynamic CGE analysis" in Journal of Asian Economics, Vol. 55, Issue C, pp. 42-57.

[22] Asian Development Bank, "Multiregional Input-Output Database, Vietnam IO Table 2017”, Manila, Philippines, 2018. https://data.adb.org/dataset/viet-nam-input-output-eco nomic-indicators (accessed on October 20, 2018).

[23] Karmanovskaya, Natalia \& Nosova, Olga \& Galishevskaya, Victoria, "Public Environmental Monitoring of the Quality of Water Bodies in Norilsk and Taimyr", Environment and Ecology Research, 9, 45-63, 2021. https://doi.org/10.13189/ eer.2021.090202

[24] Djoher, Abderrahmane, "Desalination Projects in Algeria: What Are the Environmental and Economic Issues of Seawater Desalination?", Environment and Ecology Research, 8, 59-69, 2020. https://doi.org/10.13189/eer.2020. 080301. 